This is an author produced version of a paper published in Canadian Journal of Soil Science.

This paper has been peer-reviewed and includes the final publisher proofcorrections and journal pagination.

Citation for the published paper:

Martin A. Bolinder, Thomas Kätterer, Christopher Poeplau, Gunnar Börjesson, and Leon E. Parent. (2015) Net primary productivity and belowground crop residueinputs for root crops: Potato (Solanum tuberosum L.) and sugar beet (Beta vulgaris L.). Canadian Journal of Soil Science.

Volume: 95, Number: 2, pp 87-93 http://dx.doi.org/10.4141/CJSS-2014-091.

Access to the published version may require journal subscription. Published with permission from: Agricultural Institute of Canada.

Epsilon Open Archive http://epsilon.slu.se 


\title{
Net primary productivity and below-ground crop residue inputs for root crops: Potato (Solanum tuberosum L.) and sugar beet (Beta vulgaris L.)
}

\author{
Martin A. Bolinder ${ }^{1}$, Thomas Kätterer ${ }^{1}$, Christopher Poeplau ${ }^{1,2}$, \\ Gunnar Börjesson ${ }^{3}$, and Leon E. Parent ${ }^{4}$
}

${ }^{1}$ Swedish University of Agricultural Sciences (SLU), Department of Ecology, Uppsala, Sweden (e-mail: Martin.Bolinder@slu.se); ${ }^{2}$ Thuenen Institute of Climate-Smart Agriculture, Bundesallee 50, 38106 Braunschweig, Germany; ${ }^{3}$ Swedish University of Agricultural Sciences (SLU), Department of Soil and Environment, Uppsala, Sweden; and ${ }^{4}$ Department of Soils and Agrifood Engineering, Université Laval, Québec, Canada. Received 19 September 2014, accepted 19 March 2015. Published on the web 19 March 2015.

\begin{abstract}
Bolinder, M. A., Kätterer, T., Poeplau, C., Börjesson, G. and Parent, L. E. 2015. Net primary productivity and belowground crop residue inputs for root crops: Potato (Solanum tuberosum L.) and sugar beet (Beta vulgaris $\mathbf{L}$.). Can. J. Soil Sci. 95: 87-93. Root crops are significant in agro-ecosystems of temperate climates. However, the amounts of crop residues for these crop types are not well documented and they need to be accounted for in the modeling of soil organic carbon dynamics. Our objective was to review field measurements of root biomass left in the soil as crop residues at harvest for potato and sugar beet. We considered estimates for crop residue inputs as root biomass presented in the literature and some unpublished results. Our analysis showed that compared to, for example, cereals, the contribution of below-ground net primary productivity (NPP) to crop residues is at least two to three times lower for root crops. Indeed, the field

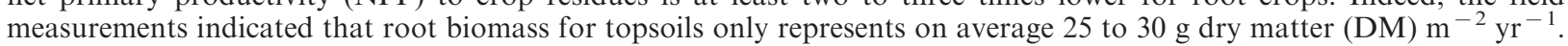
Other estimates, albeit variable and region-specific, tended to be higher. We suggest relative plant DM allocation coefficients for agronomic yield $\left(R_{P}\right)$, above-ground biomass $\left(R_{S}\right)$ and root biomass $\left(R_{R}\right)$ components, expressed as a proportion of total NPP. These coefficients, representative for temperate climates $(0.739: 0.236: 0.025$ for potato and 0.626:0.357:0.017 for sugar beet), should be useful in the modeling of agro-ecosystems that include root crops.
\end{abstract}

Key words: Roots, soil organic carbon, crop residues, agro-ecosystems, root crops

\begin{abstract}
Bolinder, M. A., Kätterer, T., Poeplau, C., Börjesson, G. et Parent, L. E. 2015. Productivité primaire nette et apport souterrain de résidus agricoles des légumes-racines : pomme de terre (Solanum tuberosum L.) et betterave sucrière (Beta vulgaris L.). Can. J. Soil Sci. 95: 87-93. Les légumes-racines forment d'importants écosystèmes agricoles dans les régions à climat tempéré. Toutefois, on ne possède pas beaucoup d'informations sur la quantité de résidus agricoles que laissent ces cultures, alors qu'il faut en tenir compte lorsqu'on veut modéliser la dynamique du carbone organique du sol. L'objectif consistait à passer en revue les relevés pris sur le terrain de la biomasse racinaire demeurée dans le sol qui constitue des résidus de culture, à la récolte de la pomme et de la betterave sucrière. Les auteurs ont tenu compte de la quantité de résidus agricoles correspondant à la masse racinaire estimée dans la littérature et de quelques résultats non publiés. Leur analyse indique qu'à l'inverse des céréales, par exemple, la productivité primaire nette souterraine des légumes racines contribue deux à trois fois moins aux résidus agricoles. A dire vrai, selon les mesures prises sur le terrain, la biomasse racinaire dans l'horizon superficiel ne représente annuellement en moyenne que 25 à $30 \mathrm{~g}$ de matière sèche par $\mathrm{m}^{2}$. D'autres estimations, quoique variables et spécifiques à une région, ont tendance à être plus élevées. Les auteurs proposent qu'on attribue un coefficient de répartition relatif de la matière sèche au rendement agronomique $\left(R_{P}\right)$, à la biomasse aérienne $\left(R_{S}\right)$ et à la biomasse racinaire $\left(R_{R}\right)$. Ces coefficients sont exprimés comme une proportion de la productivité primaire nette. De tels coefficients, en étant représentatifs des régions à climat tempéré $(0,739: 0,236: 0,025$ pour la pomme de terre et $0,626: 0,357: 0,017$ pour la betterave sucrière) devraient faciliter la modélisation des écosystèmes agricoles incluant des légumes-racines.
\end{abstract}

Mots clés: Racines, carbone organique du sol, résidus agricoles, écosystèmes agricoles, légumes-racines

Potato and sugar beet are important components of crop rotations in agro-ecosystems. Potato remains the fourth food crop (after corn, rice and wheat) for human consumption (FAOSTAT, faostat.fao.org) and sugar beet (after sugarcane) is responsible for about $20 \%$ of the world's sugar production (Anonymous 2009). The net exchange of $\mathrm{CO}_{2}$ with the atmosphere depends on the balance between the amount of net primary productivity (NPP) and its proportion returned to the soil as annual $\mathrm{C}$ inputs that remains as soil organic carbon (SOC), and the release of $\mathrm{CO}_{2}$ from the decomposition of native SOC through soil biological activity (Andrén et al. 1989; Paustian et al. 1997).

Abbreviations: AG, above-ground; DM, dry matter; NPP, net primary productivity; SOC, soil organic carbon 
The potential for sequestration and long-term storage of atmospheric $\mathrm{CO}_{2}-\mathrm{C}$ as $\mathrm{SOC}$ for different agroecosystems is usually examined with models. The main driving variable in these models is the annual $\mathrm{C}$ inputs to soil from organic amendments and above- and belowground crop residues (Bolinder et al. 2006). The belowground residue input (i.e., roots) is typically estimated from components of NPP (i.e., agronomic yields or above-ground biomass) based on root biomass measurements made in the field at the approximate time of peak above-ground biomass (i.e., close to harvest). Assumptions can also be made to account for rhizodeposition, i.e., extra-root material including root exudates and other material derived from root-turnover (Bolinder et al. 2007). Compared with the above-ground crop residue inputs, below-ground residue inputs are of particular interest because they are known to contribute more to stable SOC pools than above-ground residues (Kätterer et al. 2011).

For Canadian agro-ecosystems, Bolinder et al. (2007) reviewed literature data for common agricultural crops (cereals, soybeans and forages) and suggested an approach to estimate NPP and annual crop residue inputs to soil using relative plant allocation coefficients. Similarly, Gan et al. (2009) also derived Canadian-specific plant allocation coefficients for oilseed (canola, mustard and flax) and pulse (lentil, chick- and field-pea) crops. However, the above-mentioned as well as many other studies (e.g., Prince et al. 2001; Lokupitiya et al. 2010) on NPP and annual crop residue inputs to soil does not include any consideration for root crops such as potato and sugar beet.

Thus, there is a need to have accurate estimates of annual crop residue inputs to soil for root crops. This is important not only when predicting SOC trends over several decades, but also when these crops are present in long-term field experiments on which the SOC models are calibrated. For example, in some long-term field trials ( $>65 \mathrm{yr}$ ) root crops can represent up to $25 \%$ of the crop types present in the rotations (e.g., Carlgren and Mattsson 2001). Earlier (1950s) measurements from Germany, Russia and the Czech Republic summarized by Klimanek [1987; cited by Ludwig et al. (2007)] indicated that the average total amount of crop residues (i.e., above- plus below-ground) for potato and sugar beet represent about 200 and $100 \mathrm{~g} \mathrm{DM} \mathrm{m}^{-2} \mathrm{yr}^{-1}$, respectively. At present, with the exception of data obtained with crop growth models or inverse modelling approaches (e.g., Li et al. 1997; Meersmans et al. 2013), only a few general estimates for below-ground crop residue inputs to soil from root crops are available and they are not well documented. To our knowledge, no publication has addressed this issue in detail.

Our objective was to summarize the information available regarding annual crop residue inputs for root crops based on field measurements including some unpublished studies. We emphasize the contribution of the root system and suggest relative NPP allocation coefficients.

\section{RESULTS AND DISCUSSION}

\section{Below-ground Crop Residue Inputs}

We reviewed the available literature on root (excluding the tubers and beets) biomass measurements for potato and sugar beet that were made at or close to maturity from field studies at various locations and for different soil depths. Thereafter, these data are discussed with respect to other estimates used in the literature.

\section{Root Biomass in Field Studies}

Most of the studies we reviewed in Table 1 estimated the root biomass with conventional sampling techniques using soil cores, and only the study by Steen and Andrén (1990) measured the root biomass with ingrowth cores. For sugar beet, the two studies only measured fine roots. However, the coarse lateral roots that are attached to the beet are normally removed with the beets at harvest (Steen and Lindén 1987). The root biomass reported by Van Noordwijk et al. (1994) was also confirmed with measurements of fine root residue at harvest using minirhizotron techniques. The data from Bolinder and Parent (unpublished) were derived from a study conducted at seven on-farm sites from 2004 to 2006, under rain-fed conditions in eastern Canada (Québec). Briefly, three potato cultivars were grown on replicated largeplots on light-textured ( $>50 \%$ sand) soils. At each site, the experiments were conducted in large blocks; one cultivar was grown in each block with two to three replicates. Entire plants were sampled to determine both the above-ground (leaves and stems) and below-ground plant fractions (tubers and roots), which were expressed on a dry matter (DM) basis. Only the large roots that remained with the stems after pulling the plants were sampled. Bélanger et al. (2001) also sampled entire plants and only measured large roots. That study investigated the proportion of roots to total net primary productivity (shoots + tubers + large roots) for two cultivars, irrigated and non-irrigated that were subject to different $\mathrm{N}$ rates at two different sites over a 3-yr period.

The field measurements of total root biomass ranged from 13 to 96 and 28 to $40 \mathrm{~g}$ dry matter (DM) $\mathrm{m}^{-2}$ for potato and sugar beet, respectively (Table 1). However, on average, the total root biomass for potato and sugar beet were similar with about $35 \mathrm{~g} \mathrm{DM} \mathrm{m}^{-2}$. Considering only roots in the topsoil layer (Table 1), the values were lower for sugar beet (i.e., 24 vs. $31 \mathrm{~g} \mathrm{DM} \mathrm{m}^{-2}$ ). Potato is known as a shallow-rooted crop with most of its root biomass concentrated in the upper 20 to $30 \mathrm{~cm}$ soil layer (Joyce et al. 1979; Parker et al. 1989). Indeed, in the studies we found, only Mattsson (1991) sampled in deeper soil layers, the root biomass present below $25 \mathrm{~cm}$ represented about $20 \%$ of the total root biomass down to a $90-\mathrm{cm}$ depth. Lescynski and Tanner (1976) sampled according to rooting depth. The proportion of roots below 25 to $30 \mathrm{~cm}$ for sugar beet represented up to about $35 \%$ of the total root biomass measured to a 
Table 1. Root biomass (g dry matter $\mathrm{m}^{-2}$ ) measured at or close to maturity in field studies for potato and sugar beet at various locations and for different soil depths (cm)

\begin{tabular}{|c|c|c|c|c|}
\hline \multirow[b]{2}{*}{ Study/location } & \multirow[b]{2}{*}{ Treatment/experiment } & \multirow{2}{*}{$\begin{array}{l}\text { Total (and topsoil) } \\
\text { sampling depth }\end{array}$} & \multicolumn{2}{|c|}{ Root biomass } \\
\hline & & & Total & Topsoil \\
\hline \multicolumn{5}{|l|}{ Potato } \\
\hline Lescynski and Tanner (1976); & Conventional & 40 to 70 & 68 & - \\
\hline US & Irrigated & & 46 & 46 \\
\hline Steen and Andrén (1990); & High $\mathrm{C}$ content soil & 25 to $30(25$ to 30$)$ & 13 & 13 \\
\hline Sweden & Low $\mathrm{C}$ content soil & & 48 & 48 \\
\hline Mattsson (1991); Sweden & No $\mathrm{N}$ fertilization & $90(25)$ & 96 & 76 \\
\hline Opena and Porter (1999); US & Irrigated + fertilized & $30(30)$ & 16 & 16 \\
\hline Bélanger et al. (2001); & Non irrigated & $30(30)$ & 16 & 16 \\
\hline eastern Canada ${ }^{\mathbf{z}}$ & Irrigated & & 19 & 19 \\
\hline \multirow{3}{*}{$\begin{array}{l}\text { Bolinder and Parent } \\
\text { (unpublished); eastern Canada }\end{array}$} & cv. Goldrush & $25(25)$ & 37 & 37 \\
\hline & cv. Chieftain & & 26 & 26 \\
\hline & cv. Eramosa & & 14 & 14 \\
\hline Mean \pm standard deviation & & & $36 \pm 26$ & $31 \pm 21$ \\
\hline \multicolumn{5}{|l|}{ Sugar beet } \\
\hline Steen and Lindén (1987); & No $\mathrm{N}$ fertilization & $60(25)$ & 28 & 20 \\
\hline Sweden & $\mathrm{N}$ fertilization & & 31 & 20 \\
\hline Van Noordwijk et al. (1994); & Conventional system & $100(30)$ & 36 & 23 \\
\hline Netherlands & Integrated system & & 40 & 31 \\
\hline Mean \pm standard deviation & & & $34 \pm 5$ & $24 \pm 5$ \\
\hline
\end{tabular}

${ }^{\mathbf{z}}$ Root biomass was calculated from the proportion of large roots to total net primary productivity and is presented for the irrigated and non-irrigated treatments averaged across $\mathrm{N}$ rates (not significant) and two cultivars ( $N=12$ observations for the study). The above-ground biomass was calculated from the harvest index of the same study (Bélanger et al. 2000).

${ }^{\mathbf{y}}$ Each cultivar was subject to different $\mathrm{N}$ (130 to $250 \mathrm{~kg} \mathrm{~N} \mathrm{ha}^{-1}$ ) fertilization rates ( $N=$ a total of 16 observations for the study).

depth of 60 and $100 \mathrm{~cm}$ in the studies by Steen and Lindén (1987) and Van Noordwijk et al. (1994), respectively.

In the study by Bolinder and Parent (unpublished) the effects of $\mathrm{N}$ rates on root biomass (and marketable yields) were negligible (data not shown). However, there was a trend for a specific cultivar to have a different amount of root biomass (Table 1). The proportion of root biomass also tended to be greater for one of the cultivars in the study conducted by Bélanger et al. (2001) but their amount in terms of root biomass was similar. In that study, the response to irrigation was similar for both cultivars.

\section{Approaches to Estimate Root Biomass from Agronomic Yields}

There are some relationships that have been suggested in the literature for estimating the root biomass in the topsoil (down to 20 or $30 \mathrm{~cm}$ depth) layer as a function of the agronomic yield (i.e., tubers and beets) for potato and sugar beet (Table 2). Boiffin et al. (1986) mostly referred to values derived from the French literature. The Intergovernmental Panel on Climate Change (IPCC 2006) equations for root crops are based on general relationships between shoots and roots for other crops (according with the Tier 1 approach). The equations presented by Koga et al. (2011) are based on field measurements made in Japanese field experiments. For potato, Boiffin et al. (1986) suggest a fixed estimate.
The average yields from the Bolinder and Parent (unpublished) and the Bélanger et al. (2001) study on potato was approximately $6.5 \mathrm{Mg} \mathrm{DM} \mathrm{ha}{ }^{-1}$ (data not shown). Assuming a DM content of $20 \%$ (only wet weight yields were reported) the average yield was also about 6.5 $\mathrm{Mg} \mathrm{DM} \mathrm{ha}{ }^{-1}$ in the Lescynski and Tanner (1976) study, but slightly higher (between 8 and $9 \mathrm{Mg} \mathrm{DM}$ ha $^{-1}$ ) in the Opena and Porter (1999), Mattsson (1991) and Steen and Andrén (1990) studies. Sugar beet yield was around $10 \mathrm{Mg} \mathrm{DM} \mathrm{ha}{ }^{-1}$ in the Steen and Lindén (1987) study. Based on the above-mentioned relations to agronomic yields, we estimated the crop residue inputs from root biomass of potato and sugar beet (Fig. 1). In these calculations we used a medium-yield value of 7.0 $\mathrm{Mg} \mathrm{DM} \mathrm{ha}{ }^{-1}$ for potato and 10.0 $\mathrm{Mg} \mathrm{DM} \mathrm{ha}{ }^{-1}$ for sugar beet so that they would reflect the average yields of these experiments.

Table 2. Relationships used to estimate dry matter $\left(\mathrm{g} \mathrm{m}^{-2}\right)$ root biomass (RB) from the agronomic yield (AY) for potato and sugar beet

\begin{tabular}{lll}
\hline Reference & \multicolumn{1}{c}{ Potato } & \multicolumn{1}{c}{ Sugar beet } \\
\hline${\text { Boiffin et al. }(1996)^{\mathbf{z}}}^{\mathrm{R} B}=50$ & $\mathrm{RB}=0.06 \times \mathrm{AY} / 0.94$ \\
IPCC (2006) & $\mathrm{RB}=0.02 \times \mathrm{AY}+21.2$ & $\mathrm{RB}=0.02 \times \mathrm{AY}+21.2$ \\
Koga et al. (2011) & $\mathrm{RB}=0.0827 \times \mathrm{AY}$ & $\mathrm{RB}=0.0146 \times \mathrm{AY}$ \\
\hline
\end{tabular}

${ }^{\mathbf{z}} \mathrm{A}$ fixed estimate is suggested for potato.

${ }^{\mathrm{y}}$ Intergovernmental Panel on Climate Change. According to the Tier 1 approach. 

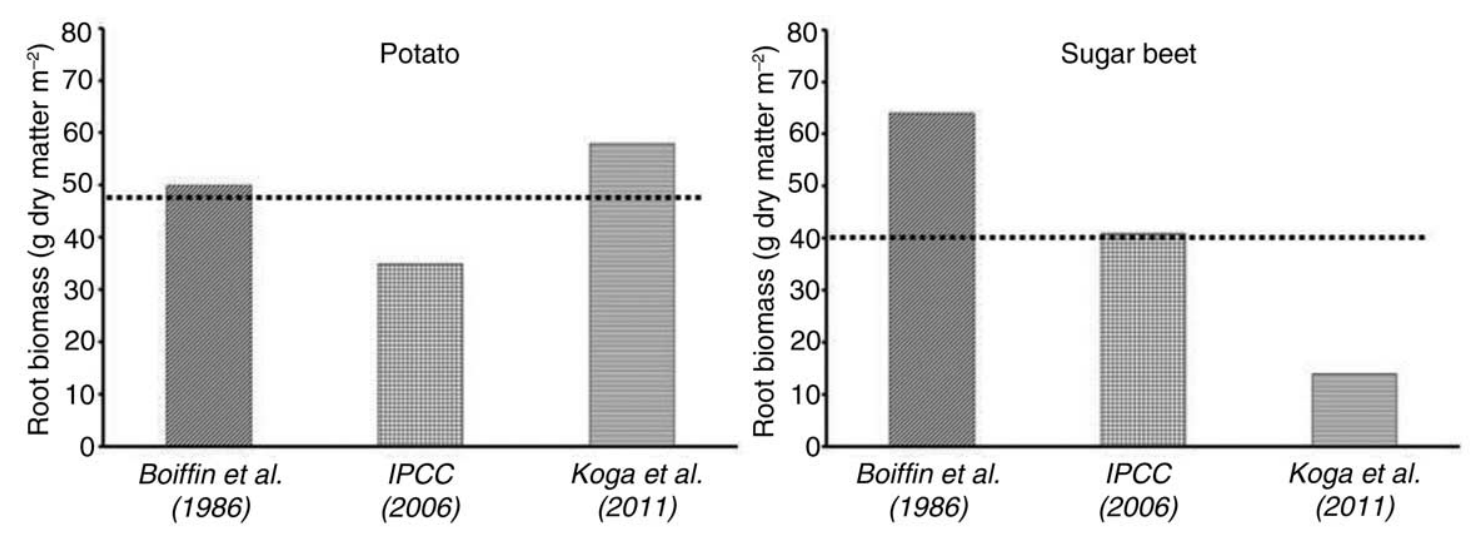

Fig. 1. Literature based values of crop residue inputs to soil as root biomass for potato and sugar beet considering estimates for an average yield of 7.0 and $10.0 \mathrm{Mg}$ dry matter (DM) ha ${ }^{-1}$, respectively. Dotted line = mean estimate (see the text for details).

The estimates of roots for potato ranged from 35 to $58 \mathrm{~g} \mathrm{DM} \mathrm{m}^{-2}$ and those of sugar beet from 14 to $64 \mathrm{~g} \mathrm{DM} \mathrm{m}^{-2}$ (Fig. 1). On average, the estimate for a potato crop was $48 \mathrm{~g} \mathrm{DM} \mathrm{m} \mathrm{m}^{-2}$ and that for sugar beet $40 \mathrm{~g} \mathrm{DM} \mathrm{m}^{-2}$. Compared with the field measurements for topsoil roots left in the field at harvest (Table 1) those estimates are 55 and $67 \%$ higher for potato and sugar beet, respectively. In particular, the root biomass for sugar beet would be over-estimated with the IPCC (2006) and Boiffin et al. (1986) equations, and underestimated with that of Koga et al. (2011). However, it should be noted that the IPCC (2006) equation was not specific for sugar beet (it was modelled after potato). Another reference suggesting estimates of the annual crop residue inputs to soil from root biomass for potato and sugar beet is that of Soltner (2000). It is mainly an "expert-opinion" based assessment, suggesting a fixed value of $80 \mathrm{~g} \mathrm{DM} \mathrm{m}^{-2}$ for an average-yielding root crop, a value that seems too high according to our analysis (Table 1 and Fig. 1).

The IPCC (2006) gave the estimates that were closest to the average values from the field measurements for potato. However, application of the IPCC (2006) formula to calculate root biomass for potato, compared with the two data sets from eastern Canada with the most detailed information available from the Bolinder and Parent (unpublished) and Bélanger et al. (2001) studies resulted in an over-estimate of about 25 and $150 \%$ for these two data-sets, respectively (data not shown). Similarly, the Koga et al. (2011) equation resulted in an over-estimate of approximately 100 and $200 \%$, respectively (data not shown). The IPCC (2006) equation also under-estimated a few data for the Bolinder and Parent (unpulished) study.

We used the two eastern Canadian data sets, which made similar measurements of root biomass for potato (with a mean root biomass of $22 \pm 9 \mathrm{~g} \mathrm{DM} \mathrm{m}^{-2} ; N=28$ ) to derive a specific equation to estimate root biomass from the agronomic yield (Fig. 2.). The Bélanger et al. (2001) root biomass data were slightly better correlated with the agronomic yields $\left(R^{2}=0.35\right)$ than the Bolinder and Parent (unpublished) data $\left(R^{2}=0.27\right)$. The combined relationship $\left(R^{2}=0.26\right)$ was $R B=0.0339 \times A Y$. Compared with the same type of equation presented by Koga et al. (2011) it can be noted (Table 2) that this combined relationship yields a root biomass that is approximately two times lower. Our correlation for the combined relationship between final tuber yields and root biomass measured close to maturity was of the same magnitude (i.e., $R^{2}=0.31$ ) as that found by Opena and Porter (1999) in the United States. A calculation with measurements (to a depth of $25 \mathrm{~cm}$ ) made in another study by Tran and Giroux (1991) from a ${ }^{15} \mathrm{~N}$ fertilizer (applied in selected micro-positions within the main plots) trial in eastern Canada also corroborates our relationship. The equation derived with those data was $R B=0.0328 \times A Y\left(R^{2}=0.61\right.$ with $N=10$, data not shown); the mean root biomass was the same as for the Bélanger et al. (2001) and Bolinder and Parent (unpublished) studies.

In the case when no regional-specific relationships are available, the average value of $31 \mathrm{~g} \mathrm{DM} \mathrm{m}^{-2}$ we calculated from the measurements of root biomass in topsoil for all studies on potato (Table 1) would constitute a reasonably good fixed approximation, recognizing the fairly high variability associated with root biomass estimates. The general IPCC (2006) equation for root crops would also be an alternative.

For other annual crops such as, for example, a mediumyield small-grain cereal (4 Mg DM ha $\left.{ }^{-1}\right)$ and graincorn (8 $\mathrm{Mg} \mathrm{DM} \mathrm{ha}{ }^{-1}$ ), annual crop residue inputs to soil from roots range from 130 to $>250 \mathrm{~g} \mathrm{DM} \mathrm{m}^{-2}$, respectively (Bolinder et al. 2007). For a potato crop, however, assuming that there are also approximately $5 \%$ of the tubers that are not harvested because they are too small or simply lost during the harvest operations (the IPCC (2006) default value for such a consideration is $8 \%$ of the marketable yield) this would increase the below-ground crop residue inputs for a mediumyield potato crop by $35 \mathrm{~g} \mathrm{DM} \mathrm{m}^{-2}$ (i.e., $0.05 \times 7.0 \mathrm{Mg}$ $\mathrm{DM} \mathrm{ha}^{-1}$ ). For most crop types, it is also common to 


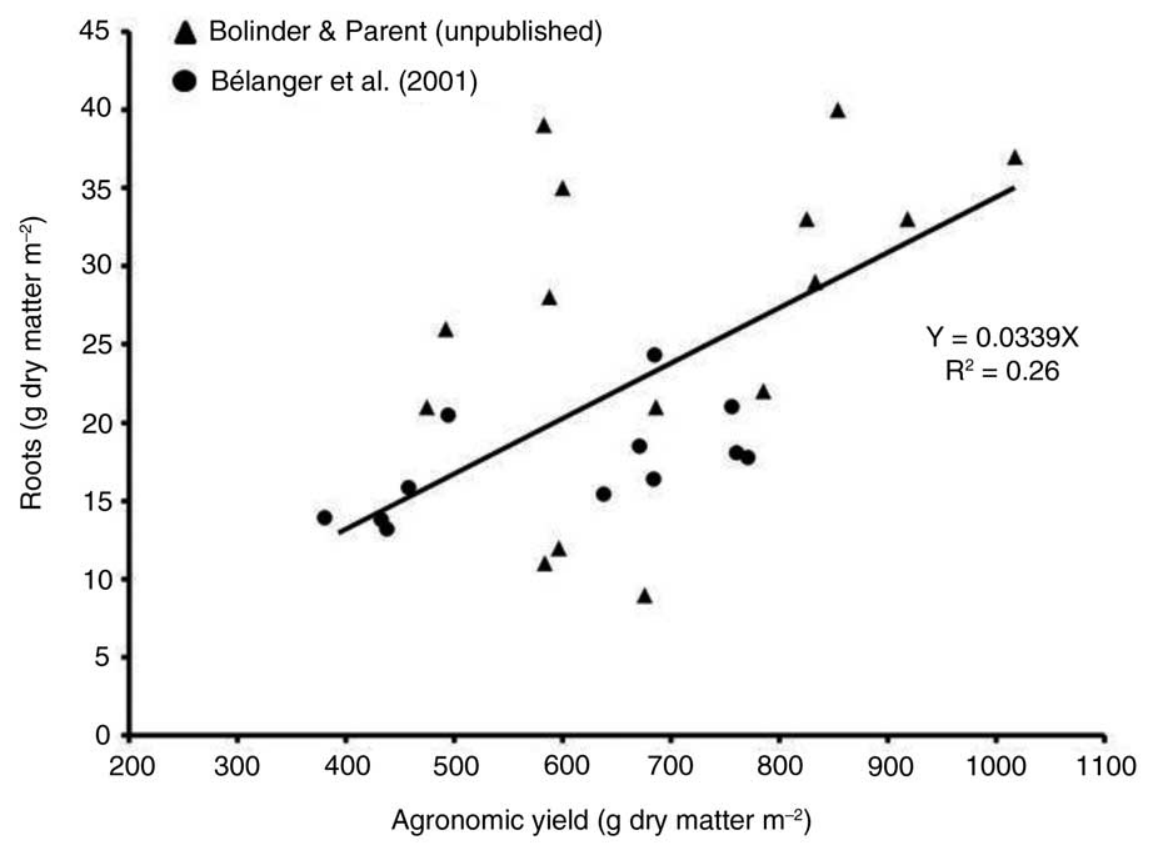

Fig. 2. Relationshsip between the agronomic yield (marketable tubers) and the measured root biomass for potato with the data from Bolinder and Parent (unpublished) and Bélanger et al. (2001).

include a coefficient to account for extra-root components, i.e., carbon from dying and decomposing roots as well as cell sloughing of epidermal root tissues during the growing season, including soluble compounds released from the roots by exudation (Kätterer et al. 2011). For example, Bolinder et al. (2007) and Gan et al. (2009) used a coefficient of 0.65 (i.e., extra-root components $=0.65 \times R B$ ) for cereals, soybeans, forages, oilseed and pulse crops. The contribution of extra-root components to the below-ground crop residue inputs has mostly been assessed for small-grain cereals, forages and natural grasslands (e.g., Kuzyakov and Domanski 2000; Gill et al. 2002). There is also a contribution from extra-root that occurs for root crops (e.g., root turnover during the growing season), but there are to our knowledge no studies available that have quantified this contribution as a whole (i.e., taking into account all parts of the extra-root components). Nevertheless, compared with other annual crops, crop residue inputs from root biomass for a potato and sugar beet crop remain much lower.

\section{Above-ground Crop Residue Inputs}

The estimation of above-ground (AG) crop residues (i.e., potato vines) returned to the soil for potato as a function of the marketable yields are somewhat complicated by the fact that there is typically a vine killing (chemical) that takes place a few weeks prior to harvest. During maturation the tubers also accumulate additional dry weight, while the dry matter in tops decreases because there is carbon translocation to the tubers (Westermann 1993). Therefore, for a potato crop it is difficult to have simultaneous measurements for AG biomass and agronomic yields (as tubers) at harvest. Boiffin et al. (1986) considered AG crop residue from potato as negligible, and Soltner (2000) suggested no value. The AG crop residues were also measured in the root studies by Bolinder and Parent (unpublished) and by Bélanger et al. (2001). According to these data we used the average relationship $A G$ crop residue $=0.32 \times A Y$, where the proportions of crop residues in the two studies represented $0.26 \pm 0.11$ and $0.37 \pm 0.19$, respectively. For an average yield of $7.0 \mathrm{Mg} \mathrm{DM} \mathrm{ha}^{-1}$ this amounts to $\mathrm{AG}$ crop residues in the range of about 180 to $260 \mathrm{~g} \mathrm{DM} \mathrm{m}^{-2}$. The proportions used in IPCC (2006) are $0.27 \pm 0.04$.

Contrary to potato, the above-ground biomass for sugar beet is more important but can often also be exported from the field and used, e.g., for animal feed. The studies on root biomass for sugar beet (Table 1) did not make a detailed discussion on measurements for the proportions of AG crop residues as a function of the agronomic yields, only the Steen and Lindén (1987) study indicated that it was about $40 \%$. However, to have a robust estimate we examined this relationship from a Swedish database for long-term (initiated in 1957) field experiments where this relationship is periodically being assessed. Averaged across six of these soil fertility experiments located in southern Sweden for the period 1964-1972 [calculated from data in Jansson (1975)] indicated that it was $A G$ crop residues $=0.46 \times A Y$ for normal to high $\mathrm{PK}$ and $\mathrm{N}$ fertilization rates (140 to $210 \mathrm{~kg} \mathrm{~N} \mathrm{ha}^{-1}$ ). The variability between sites [calculated from data in Agerberg (1961)] was fairly low (coefficient 
of variation $\approx 10 \%$ ). The relationships are continuously revised in this database and the average relationship (unpublished data) of $A G$ crop residues $=0.57 \times A Y$ is used since the mid-1990s (for the same $\mathrm{N}$ application rates mentioned above). This is similar to the equation (i.e., $A G$ crop residues $=0.6 \times A Y$ ) suggested by Boiffin et al. (1986). Therefore, if AG crop residues are left in the field, according to the latest relationship used in the Swedish database, they would represent about $570 \mathrm{~g} \mathrm{DM} \mathrm{m}^{-2}$ for an average-yielding (10.0 Mg DM ha ${ }^{-1}$ ) sugar beet crop, a value that is twice as high as that for a potato crop. A fixed value of $400 \mathrm{~g} \mathrm{DM} \mathrm{m}^{-2}$ was suggested by Soltner (2000).

\section{Relative Net Primary Productivity Allocation Coefficients}

We calculated allocation coefficients relative to NPP. This was done following the approach described in detail by Bolinder et al. (2007), but excluding the extraroot component. Briefly, the NPP is partitioned into three coefficients (relative to total NPP) as follows: $R_{\mathrm{P}}=\mathrm{C}_{\mathrm{P}} / \mathrm{NPP}, R_{\mathrm{S}}=\mathrm{C}_{\mathrm{S}} / \mathrm{NPP}$ and $R_{\mathrm{R}}=\mathrm{C}_{\mathrm{R}} / \mathrm{NPP}$. Where $\mathrm{C}_{\mathrm{P}}=$ the agronomic yield (tubers), $\mathrm{C}_{\mathrm{S}}=$ above-ground biomass and $\mathrm{C}_{\mathrm{R}}=$ root biomass. By definition $R_{\mathrm{P}}+R_{\mathrm{S}}+$ $R_{\mathrm{R}}=1$. These coefficients are then used to calculate the corresponding value of each NPP constituent, usually as a function of $\mathrm{C}_{\mathrm{P}}$, e.g., $\mathrm{C}_{\mathrm{S}}=\left(R_{\mathrm{S}} / R_{\mathrm{P}}\right) \times \mathrm{C}_{\mathrm{P}}$.

When using the relationship determined with the most detailed data available, for the two data sets for eastern Canada (Fig. 2), and the average proportion as aboveground biomass from these two studies, the coefficients for potato are as follows: 0.739: 0.236: 0.025 . For sugar beet, calculating the NPP allocation coefficients using the average data of field measurements available for roots in the topsoil (Table 1) and the latest relationship for above-ground biomass in the Swedish database, the coefficients for sugar beet are: 0.626: 0.357: 0.017.

The uncertainty in these coefficients is related to the variability in the yield data and in the above- and belowground biomass measurements. For the two potato datasets, the coefficient of variation $(\mathrm{CV}, \%)$ was $25 \%$ for the marketable yield and $46 \%$ for the above-ground biomass, representing fairly typical variations in field experiments. For the root biomass measurements it was $40 \%$. With respect to root biomass, the variations in measurements are generally high. For example, the CV associated with the measurements reviewed for smallgrain cereals and forages in Bolinder et al. (2007) was 80 and $70 \%$, respectively, similar to that reported for other reviews (Amos and Walters 2006; Bolinder et al. 2012). However, these relative allocation coefficients can be refined, and the uncertainty reduced when new measurements for root crops emerge. Our knowledge on below-ground allocation remains limited and more field measurements are needed.

\section{CONCLUSIONS}

The review of field measurements and other available generic relationships in this study indicates that the annual root-derived crop residue inputs to topsoil for average-yielding potato and sugar beet crops are in the range of about 30 to 50 and 25 to $40 \mathrm{~g} \mathrm{DM} \mathrm{m}^{-2}$, respectively. This contribution of below-ground NPP to annual crop residue inputs to soil for root crops are much lower compared with those for other annual crops, regardless of whether extra-root components and un-harvested tubers are also accounted for. The eastern Canadian-specific relative NPP allocation coefficients proposed for potato are complementary to those previously suggested for other commonly grown crops in Canada. These results should contribute to a better modeling of SOC dynamics for agro-ecosystems that include root crops.

\section{ACKNOWLEDGEMENTS}

This work was funded by the Swedish Farmer's Foundation for Agricultural Research within the project "How do catch-crops, harvest residues, manure and mineral fertilizers affect yield potential and soil organic matter?" Financial support was also provided by the NSERC project CRDPJ-385199 on ecosystem services and collaborative potato farms in eastern Canada.

Agerberg, S. 1961. Kombinerade växtföljds- och gödlingsförsök i Malmöhus län. [Trials with different intensities of fertilization to different rotations in South Sweden]. Statens Jordbruksförsök, Särtryck och småskrifter. 144: 1-39 [in Swedish with English Summary].

Amos, B. and Walters, T. 2006. Maize root biomass and net rhizodeposited carbon: An analysis of the literature. Soil Sci. Soc. Am. J. 70: 1489-1503.

Andrén, O., Lindberg, T., Boström, U., Clarholm, M., Hansson, A-C., Johansson, G., Lagerlöf, J., Paustian, K., Persson, J., Pettersson, R., Schnurer, J., Sohlenius, B. and Wivstad, M. 1989. Chapter 5. Organic carbon and nitrogen flows. In O. Andrén, T. Lindberg, K. Paustian, and T. Rosswall, eds. Ecology of arable land - organisms, carbon and nitrogen cycling. Ecol. Bull. (Copenhagen) 40: 85-125.

Anonymous. 2009. Agribusiness handbook: Sugar beet, white sugar. The Food and Agriculture Organization of the United Nations, Rome, Italy.

Bélanger, G., Walsh, J. R., Richards, J. E., Milburn, P. H. and Ziadi, N. 2001. Tuber growth and biomass partitioning of two potato cultivars grown under different $\mathrm{N}$ fertilization rates with and without irrigation. Am. J. Pot. Res. 78: 109-117.

Bélanger, G., Walsh, J. R., Richards, J. E., Milburn, P. H. and Ziadi, N. 2000. Yield response of two potato cultivars to supplemental irrigation and $\mathrm{N}$ fertilization in New Brunswick. Am. J. Pot. Res. 77: 11-21.

Boiffin, J., Keli Zaghabi, J. and Sebilotte, M. 1986. Système de culture et statut organique des sols dans le Noyonnais: application du modèle de Hénin-Dupuis. Agronomie 6: 437-446 [in French].

Bolinder, M. A., Janzen, H. H., Gregorich, E. G., Angers, D. A. and VandenBygaart, A. J. 2007. An approach for estimating net primary productivity and annual carbon inputs to soil for common agricultural crops in Canada. Agric. Ecosyst. Environ. 118: 29-42.

Bolinder, M. A., Kätterer, T., Andrén, O. and Parent, L. E. 2012. Estimating carbon inputs to soil in forage-based crop 
rotations and modeling the effects on soil carbon dynamics in a Swedish long-term field experiment. Can. J. Soil Sci. 92: 821-833.

Bolinder, M. A., VandenBygaart, A. J., Gregorich, E. G., Angers, D. A. and Janzen, H. H. 2006. Modeling soil organic carbon stock change for estimating whole-farm greenhouse gas emissions. Can. J. Soil Sci. 86: 419-429.

Carlgren, K. and Mattsson, L. 2001. Swedish soil fertility experiments. Acta Agric. Scand. Sect. B, Soil Plant Sci. 51: 49-76.

Gan, Y. T., Campbell, C. A., Janzen, H. H., Lemke, R. L., Basnyat, P. and McDonald, C. L. 2009. Carbon input to soil from oilseed and pulse crops on the Canadian prairies. Agric. Ecosyst. Environ. 132: 290-297.

Gill, R. A., Kelly, R. H., Parton, W. J., Day, K. A., Jackson, R. B., Morgan, J. A., Scurlock, J. M. O., Tieszen, L. L., Castle, J. V., Ojima, D. S. and Zhang, X. S. 2002. Using simple environmental variables to estimate below-ground productivity in grasslands. Global Ecol. Biogeogr. 11: 79-86.

Intergovernmental Panel on Climate Change. 2006. 2006 IPCC guidelines for national greenhouse gas inventories. Vol. 4. Agriculture, Forestry and Other Land Use. Institute for Global Environmental Strategies, Hayama, Japan.

Jansson, S. L. 1975. Bördighetsstudier för markvård - Försök i Malmöhus län 1957-74. [Long-term soil fertility studies Experiments in Malmöus län 1957-74]. J. R. Swed. Acad. Agric. For. Suppl. 10: 1-60 [in Swedish with English Summary].

Joyce, R., Steckel, A. and Gray, D. 1979. Drought tolerance in potatoes. J. Agric. Sci. (Camb.) 92: 375-381.

Kätterer, T., Bolinder, M. A., Andén, O., Kirchmann, H. and Menichetti, L. 2011. Roots contribute more to refractory soil organic matter than above-ground crop residues, as revealed by a long-term field experiment. Agric. Ecosyst. Environ. 141: 184-192.

Klimanek, E.-M. 1987. Ernte- und Wurzeldrückstände Landwirtschaftlich Genutzer Frucharten. Akademie der Landwitschaftwissenschaften der DDR, Müncheberg, Germany [in German].

Koga, N., Smith, P., Yeluripati, J. B., Shirato, Y., Kimura, S. D. and Nemoto, M. 2011. Estimating net primary production and annual plant carbon inputs, and modelling future changes in soil carbon stocks in arable farmlands of northern Japan. Agric. Ecosyst. Environ. 144: 51-60.

Kuzyakov, Y. and Domanski, G. 2000. Carbon input by plants into the soil. J. Plant Nutr. Soil Sci. 163: 421-431.

Lescynski, D. B. and Tanner, C. B. 1976. Seasonal variation of root distribution of irrigated, field grown Russet Burbank potato. Am. Potato J. 53: 69-78.

Li, C., Frolking, S., Crocker, G. J., Grace, P. R., Klir, J., Körschens, M. and Poulton, P. R. 1997. Simulating trends in soil organic carbon in long-term experiments using the DNDC model. Geoderma 81: 45-60.
Lokupitiya, E., Paustian, K., Easter, M., Williams, S., Andrén, O. and Kätterer, T. 2010. Carbon balance in US croplands during the last two decades of the twentieth century. Biogeochemistry 107: 207-225. DOI: 10.1007/s10533-010-9546-y. Ludwig, B., Schulz, E., Rethemeyer, J., Merbach, I. and Flessa, H. 2007. Predictive modelling of $\mathrm{C}$ dynamics in the long-term fertilization experiment at Bad Lauchstädt with the Rothamsted carbon model. Eur. J. Soil Sci. 58: 1155-1163.

Mattsson, L. 1991. Nitrogen mineralization and root production in some common arable crops. Swedish University of Agricultural Sciences, Department of Soil Sciences, Uppsala, Sweden. Report no. 182 [in Swedish].

Meersmans, J., Martin, M. P., Lacarce, E., Orton, T. G., De Baets, S., Gourrat, M., Saby, N. P. A., Wetterlind, J., Bispo, A., Quine, T. A. and Arrouays, D. 2013. Estimation of soil carbon input in France: An inverse modelling approach. Pedosphere 23: 422-436.

Opena, G. B. and Porter, G. A. 1999. Soil management and supplemental irrigation effects on potato: Root growth. Agron. J. 91: 426-431.

Parker, C. J., Carr, M. K. V., Jarvis, N. J., Evans, M. T. B. and Lee, V. H. 1989. Effects of subsoil loosening and irrigation on soil physical properties, root distribution and water uptake of potatoes (Solanum tuberosum). Soil Tillage Res. 13: 267-285.

Paustian, K., Collins, H. P. and Paul, E. A. 1997. Management controls on soil carbon. Pages 15-49 in E. A. Paul et al., eds. Soil organic matter in temperate agroecosystems. Long-term experiments in North America. CRC Press, Boca Raton, FL. Prince, S. D., Haskett, J., Steininger, M., Strand, H. and Wright, R. 2001. Net primary production of U.S. Midwest croplands from agricultural harvest yield data. Ecol. Appl. 11: 1194-1205.

Soltner, D. 2000. Les grandes productions végétales: phytotechnie spéciale. Collection sciences et techniques agricoles [in French].

Steen, E. and Andrén, O. 1990. Effects of metribuzin on potato root growth. Swed. J. Agric. Res. 20: 127-133.

Steen, E. and Lindén, B. 1987. Role of fine roots in the nitrogen economy of sugar beet. J. Agron. Crop Sci. 158: 1-7.

Tran, T.S. and Giroux, M. 1991. Effects of N rates and harvest dates on the efficiency of ${ }^{15} \mathrm{~N}$-labelled fertilizer on early harvested potatoes (Solanum tuberosum L.). Can. J. Soil Sci. 71: 519-532.

Van Noordwijk, M., Brouver, G., Koning, H., Meijboom, F. W. and Grzebisz, W. 1994. Production and decay of structural root material of winter wheat and sugar beet in conventional and integrated cropping systems. Agric. Ecosyst. Environ. 51: 99-113.

Westermann, D. T. 1993. Potato health management. The American Phytopathological Society, St. Paul, MN. 178 pp. 